Themed Issue: Assisted Reproductive Treatments (ART) and DOHAD

\title{
The health outcomes of human offspring conceived by assisted reproductive technologies (ART)
}

\author{
M. Chen ${ }^{1}$ and L. K. Heilbronn ${ }^{2,3 *}$ \\ ${ }^{1}$ Shanghai First Maternity and Infant Hospital, Tongji University School of Medicine, Shanghai, China \\ ${ }^{2}$ Discipline of Medicine, University of Adelaide, Adelaide, SA, Australia \\ ${ }^{3}$ Research Centre for Reproductive Health, Robinson Research Institute, University of Adelaide, Adelaide, SA, Australia
}

\begin{abstract}
Concerns have been raised about the health and development of children conceived by assisted reproductive technologies (ART) since 1978 . Controversially, ART has been linked with adverse obstetric and perinatal outcomes, an increased risk of birth defects, cancers, and growth and development disorders. Emerging evidence suggests that ART treatment may also predispose individuals to an increased risk of chronic ageing related diseases such as obesity, type 2 diabetes and cardiovascular disease. This review will summarize the available evidence on the short-term and long-term health outcomes of ART singletons, as multiple pregnancies after multiple embryos transfer, are associated with low birth weight and preterm delivery, which can separately increase risk of adverse postnatal outcomes, and impact long-term health. We will also examine the potential factors that may contribute to these health risks, and discuss underlying mechanisms, including epigenetic changes that may occur during the preimplantation period and reprogram development in utero, and adult health, later in life. Lastly, this review will consider the future directions with the view to optimize the long-term health of ART children.
\end{abstract}

Received 3 November 2016; Revised 4 March 2017; Accepted 14 March 2017; First published online 18 April 2017

Key words: assisted reproductive technologies (ART); In vitro fertilization (IVF); intracytoplasmic sperm injection (ICSI); singletons; health outcomes

\section{Assisted reproduction technologies (ART)}

ART are defined as all treatments or procedures for initiating pregnancy that include the in vitro handling of both oocytes and sperm or embryos, predominantly in vitro fertilization (IVF), intracytoplasmic sperm injection (ICSI), gamete and embryo cryopreservation, preimplantation genetic diagnosis and preimplantation genetic screening. ${ }^{1}$ Briefly, the routine IVF procedure includes three steps: ovarian hyperstimulation, IVF and embryo culture, and embryo transfer. First, high doses of gonadotropins are administrated to induce development of multiple follicles. Then, the oocytes are retrieved from the ovaries using a transvaginal ultrasound-guided fine needle and inseminated with the prepared sperm in vitro to achieve fertilization. Embryos are cultured in a prepared medium in the incubator for 3 days to reach the eight-cell stage or 5 days to develop to the blastocyst stage. Finally, the embryos are transferred into the uterus or frozen for future transfer. Although IVF is beneficial for most of infertile couples with female infertility, unexplained infertility and some cases of male infertility, ICSI in which a single spermatozoon is injected into the oocyte cytoplasm is required to treat severe male infertility.

Since 1978, more than 5 million children have been born by ART treatment, mostly by IVF and ICSI. ${ }^{2}$ Concerns about the potential health implications of ART remain., ${ }^{3,4}$ Increasing

*Address for correspondence: Dr L. Heilbronn, Level 7, Nutrition and

Metabolism, SAHMRI, North Terrace, Adelaide, SA 5000, Australia.

(Email leonie.heilbronn@adelaide.edu.au) evidence shows ART treatment is associated with adverse perinatal outcomes, which are related to subfertility of patients, multiple pregnancies and ART technologies. ${ }^{4-9}$ As it is well accepted that multiple pregnancies, after multiple embryos transfer, are associated with low birth weight and preterm delivery, ${ }^{10}$ which can also impact long-term health risks, this review will limit its focus to the health outcomes of ART singletons born from IVF and ICSI $v$. singletons from natural conception.

\section{Obstetric and perinatal outcome in ART singleton pregnancies}

As summarized in Table 1, singleton pregnancies after ART are associated with adverse obstetric and perinatal outcome as compared with spontaneous conception. ${ }^{4,11,12}$ These outcomes include an increased risk of low birth weight, preterm birth, small for gestational age, stillbirth, perinatal mortality, admission to a neonatal intensive care unit, antepartum haemorrhage, hypertensive disorders of pregnancy, preterm rupture of membranes, gestational diabetes, induction of labour and caesarean section. ${ }^{8,11-17}$ It should be noted that vanishing twin pregnancies, which contribute to about $10 \%$ of IVF singletons pregnancies, increase perinatal risk in IVF singletons. ${ }^{18,19}$ However, whether the procedure of IVF itself, or the underlying parental characteristics or genetics are the main contributors to this increase in obstetric and perinatal risk is not clear. Some studies have shown that IVF singletons have an increased risk of adverse perinatal outcome $v$. their non-IVF siblings. ${ }^{11}$ However, other studies have shown 
Table 1. Obstetric and perinatal outcome in in vitro fertilization (IVF) singleton pregnancies

\begin{tabular}{|c|c|c|c|}
\hline Participants & Year of birth & Outcomes & References \\
\hline Siblings born after IVF-ICSI $v$. spontaneous conception $(n=7758)$ & 1994-2006 & $\begin{array}{l}\text { Low birth weight (aOR, 1.4; 95\% CI, 1.1-1.7) and preterm } \\
\text { birth (aOR, } 1.3 ; 95 \% \mathrm{CI}, 1.1-1.6)\end{array}$ & 12 \\
\hline Siblings born after IVF-ICSI $v$. spontaneous conception $(n=545,102)$ & 1999-2007 & $\begin{array}{l}\text { An association between maternal characteristics and a lower } \\
\text { birth weight, ranging from }-7 \mathrm{~g}(95 \% \mathrm{CI},-40 ; 26) \text { to } \\
-101 \mathrm{~g}(95 \% \mathrm{CI},-170 ;-32)\end{array}$ & 23 \\
\hline ART births $(n=4333) v$. spontaneous conception $(n=295,220)$ & 1986-2002 & Low birth weight $(P<0.001)$ and preterm birth $(P<0.001)$ & 15 \\
\hline IVF $(n=133)$, ICSI $(n=104) v$. spontaneous conception $(n=338)$ & $1998-2003$ & Preterm birth $(P<0.01)$ & 17 \\
\hline IVF/ICSI $(n=742) v$. spontaneous conception $(n=16,525)$ & $(1989-2006)$ & Stillbirth (aOR: 4.08; 95\% CI, 2.11-7.93) & 8 \\
\hline $\operatorname{IVF}(n=11347) v$. spontaneous conception $(n=571,914)$ & 2002-2006 & $\begin{array}{l}\text { Low birth weight }(\mathrm{aOR}, 1.13 ; 95 \% \mathrm{CI}, 1.02-1.25) \text { and } \\
\text { preterm birth (aOR, 1.15; 95\% CI, 1.06-1.25) }\end{array}$ & 168 \\
\hline ART vanishing co-twin $(n=642) v$. ART singletons $(n=5237)$ & 1995-2001 & $\begin{array}{l}\text { Low birth weight (aOR, } 1.7 ; 95 \% \mathrm{CI}, 1.2-2.2) \text {; preterm birth } \\
\quad(\mathrm{aOR}, 1.3 ; 95 \% \mathrm{CI}, 1.0-1.7) \\
\text { Child death }(\mathrm{aOR}, 3.6 ; 95 \% \mathrm{CI}, 1.7-7.6) \text {; small-for-gestational } \\
\quad \text { age (OR, } 1.50 ; 95 \% \mathrm{CI}, 1.03-2.20)\end{array}$ & 18,19 \\
\hline $\begin{array}{l}\text { Time to pregnancy }>1 \text { year }(n=3899) v \text {. time to pregnancy } \leqslant 1 \text { year } \\
\quad(n=15302)\end{array}$ & $1997-2001$ & Preterm birth (aOR, 1.38; 95\% CI, 1.14-1.69) & 20 \\
\hline $\begin{array}{l}\text { Time to pregnancy }>1 \text { year }(n=5722) \text {, infertility treatment }(n=4271) v \text {. } \\
\quad \text { time to pregnancy } \leqslant 1 \text { year }(n=50,614)\end{array}$ & $1997-2003$ & $\begin{array}{l}\text { Small-for-gestational age (aOR, 1.24; 95\% CI, 1.1-1.4) and } \\
\quad(\mathrm{aOR}, 1.4 ; 95 \% \mathrm{CI}, 1.23-1.6)\end{array}$ & 21 \\
\hline Frozen embryo transfer $(n=746) v$. fresh embryo transfer $(n=762)$ & 2013-2014 & $\begin{array}{l}\text { Live birth (rate ratio, } 1.17 ; 95 \% \mathrm{CI}, 1.05-1.31 \text { ); pregnancy loss } \\
\text { (rate ratio, } 0.67 ; 95 \% \mathrm{CI}, 0.54-0.83 \text { ); and ovarian } \\
\text { hyperstimulation syndrome (rate ratio, } 0.19 ; 95 \% \mathrm{CI}, 0.10- \\
0.37 \text { ), preeclampsia (rate ratio, } 3.12 ; 95 \% \mathrm{CI}, 1.26-7.73 \text { ) }\end{array}$ & 24 \\
\hline Unstimulated IVF $(n=190) v$. stimulated IVF $(n=174)$ & $2007-2013$ & Low birth weight (aOR, $0.11 ; 95 \% \mathrm{CI}, 0.01-1.0)$ & 26 \\
\hline Unstimulated IVF $(n=6168) v$. stimulated IVF cycles $(n=584,835)$ & $1991-2011$ & $\begin{array}{l}\text { Preterm birth (aOR, } 1.43 ; 95 \% \mathrm{CI}, 0.91-2.26) \\
\text { Low birth weight (aOR, } 1.58 ; 95 \% \mathrm{CI}, 0.96-2.58)\end{array}$ & 27 \\
\hline IVF births $(n=3305) v$. the general population $(n=1,505,724)$ & 1982-1995 & $\begin{array}{l}\text { Very preterm birth }(<32 \text { weeks) (OR, 3.54; 95\% } \\
\text { CI, 2.90-4.32) } \\
\text { Very low birth weight }(<1500 \mathrm{~g})(\mathrm{OR}, 4.39 ; 95 \% \\
\text { CI, 3.62-5.32) }\end{array}$ & 94 \\
\hline
\end{tabular}

ICSI, intracytoplasmic sperm injection; CI, confidence intervals; ART, assisted reproductive technologies; aOR, adjusted odds ratio; OR, odds ratio. 
that perinatal outcomes from spontaneous conception are also poorer in subfertile women $v$. those with normal fertility, ${ }^{20,21}$ and that perinatal outcomes are comparable after IVF or natural conception in subfertile women. ${ }^{22}$ A large recent study using siblingship analysis suggested that maternal characteristics such as subfertility and maternal age but not IVF treatment are associated with lower birth weight in IVF children. ${ }^{23}$ This discrepancy in the literature requires further study in larger cohorts that control for as many confounders as possible, and also further pre-clinical study. When investigating risk, the type of ART procedure is not always reported, and may contribute to adverse perinatal outcomes. A recent study shows that frozen embryo transfer increases pregnancy rates, improves obstetric and perinatal outcomes, and reduces the risk of ovarian hyperstimulation syndrome in patients with polycystic ovary syndrome. ${ }^{24}$ A meta-analysis of 11 studies supports this, reporting that singletons born after the transfer of frozen thawed embryos had better obstetric and perinatal outcome as compared with those after the transfer of fresh IVF embryos. ${ }^{25}$ The relative risks (RR) and 95\% confidence intervals (CI) of antepartum haemorrhage ( $\mathrm{RR}=0.67,95 \%$ $\mathrm{CI}, 0.55-0.81)$, preterm birth $(\mathrm{RR}=0.84,95 \% \mathrm{CI}$, $0.78-0.90)$, small for gestational age $(\mathrm{RR}=0.45,95 \% \mathrm{CI}$, $0.30-0.66)$, low birth weight $(\mathrm{RR}=0.69,95 \% \mathrm{CI}$, $0.62-0.76)$ and perinatal mortality $(\mathrm{RR}=0.68,95 \% \mathrm{CI}$, 0.48-0.96) were lower in women who received frozen embryos. ${ }^{25}$ The characteristics for each study was shown in the review. ${ }^{25}$ This data suggests that suboptimal endometrial development, induced by hormone stimulation, may be a contributor to poorer perinatal outcome after IVF. ${ }^{7,12}$ A recent retrospective cohort study suggests natural cycle IVF may decrease the risk of low birth weight $v$. conventional stimulated IVF, ${ }^{26}$ but this is not reported universally. ${ }^{27}$ The length of embryo culture is emerging as another potential confounder when considering perinatal outcomes, but consideration may also be required as to whether sequential or single-step culture media is employed. ${ }^{28}$ Increasing evidence suggests the type of culture medium may also impact birth weight in IVF singletons. ${ }^{29,30}$ Although some studies show that blastocyst transfer is associated with a higher cumulative live birth and pregnancy rates, ${ }^{31}$ a recent meta-analysis of six studies suggest that blastocyst transfer may increase the risk of preterm birth in IVF singleton pregnancies. ${ }^{32}$ Taken together, it seems that parental characteristics, and ART procedures themselves contribute to the adverse perinatal outcomes of singleton pregnancies after ART. Careful further studies are warranted to determine whether cleavage embryo transfer, sequential media with blastocyst transfer, minimal stimulation protocols or natural IVF improve obstetric and perinatal outcomes, and the long-term health outcomes of this on ART children.

\section{Birth defects in ART singleton pregnancies}

Major malformations were defined as those causing functional impairment or requiring surgical correction, ${ }^{33,34}$ whereas the others were considered minor malformations. The prevalence of major birth defects such as chromosomal and musculoskeletal defects diagnosed by 1 year of age is two-fold higher in infants conceived by IVF or ICSI than in naturally conceived infants born between 1993 and 1997 in Western Australia. ${ }^{35}$ Importantly, this study controlled for parental factors such as maternal age and parity, the gender of the infant and correlation between siblings. In Israel, the percentage of major malformations in infants conceived by ART in 1986-1994 and 1995-2002 was also double that of the general population during the same periods. ${ }^{36}$ Similar reports have been observed in Spain, ${ }^{37}$ France, ${ }^{38}$ Canada $^{39}$ and the United States ${ }^{40,41}$ (summarized in Table 2).

Large meta-analyses have been conducted and show that children born after ART have a 30-40\% increased risk of birth defects compared with spontaneous conceptions. ${ }^{42-47}$ However, it is not entirely clear if the contributing factor is the ART procedure, or the underlying infertility itself. One Italian study of $>7000$ infants born after ART or ovulation induction suggested the increased prevalence of birth defects associated with non-spontaneous conception was largely due to confounding factors such as maternal age, ${ }^{48}$ which is associated with poorer oocyte quality, mitochondrial dysfunction, aneuploidy and epigenetic alteration. ${ }^{49}$ A large Danish longitudinal study found singletons born of infertile couples who conceived naturally (time to pregnancy $>12$ months) or after infertility treatment including different types of ART or surgeries had a higher prevalence of congenital malformations compared with singletons born of fertile couples (time to pregnancy $\leqslant 12$ months). ${ }^{50}$ Notably, the prevalence of congenital malformations increased with increasing time to pregnancy, suggesting that infertility per se was an independent risk factor. On the other hand, amongst infertile couples, infertility treatment was associated with an increased prevalence of genital organ malformations in singletons compared with natural conception. ${ }^{50}$ Further, Davies et al. ${ }^{15}$ compared risks of birth defects among pregnancies in women who received ART treatment, spontaneous pregnancies in women who had a previous birth with assisted conception and spontaneous pregnancies in women with or without a record of infertility. An increased risk of birth defects was significantly associated with infertility per se, independently of assisted conception. An increased risk of birth defects was also associated with assisted conception after the multivariate adjustment, however, this association was only observed in births conceived by ICSI but not by IVF, after adjustments. ${ }^{15}$ In comparison, two metaanalysis reported the risk of birth defect was not significantly different between children conceived by IVF and ICSI. ${ }^{45,51}$

Ovulation induction alone has also been associated with increased risk of birth defects. ${ }^{39,52}$ Evidence shows that exogenous gonadotrophins may impair oocyte and embryo development as well as endometrial receptivity, increase chromosomal aneuploidy, alter epigenetic modifications, thus have detrimental effects on perinatal outcomes and long-term health. ${ }^{53,54}$ In Finland, ART singleton girls from ovulation 
Table 2. Birth defects in in vitro fertilization (IVF) singleton pregnancies

\begin{tabular}{|c|c|c|c|}
\hline Participants & Year of birth & Outcomes & References \\
\hline $\begin{array}{l}\text { ART births }(n=1138) v \text {. spontaneous } \\
\quad \text { conception }(n=4000)\end{array}$ & 1993-1997 & $\begin{array}{l}\text { Major defects: IVF (aOR, 2.0; 95\% CI, 1.5-2.9); } \\
\text { ICSI (aOR, 2.0; 95\% CI, 1.3-3.2) }\end{array}$ & 35 \\
\hline $\begin{array}{l}\text { IVF births }(n=31,007) v \text {. spontaneous } \\
\quad \text { conception }(n=278)\end{array}$ & $1986-1994$ & Major defects: IVF (OR, 2.3) & 36 \\
\hline $\begin{array}{l}\text { ART births }(n=53208) v \text {. spontaneous } \\
\quad \text { conception }(n=1632)\end{array}$ & $1995-2002$ & Major defects: ART (OR, 1.75) & \\
\hline $\begin{array}{l}\text { Cases with major birth defects }(n=1905) v \text {. } \\
\quad \text { controls }(n=2722)\end{array}$ & 1992-2007 & ART (aOR, 2.7; 95\% CI, 1.8-4.1) & 37 \\
\hline $\begin{array}{l}\text { Cases with congenital heart defects } \\
\qquad \begin{array}{l}n=5493) v \text {. malformed controls } \\
(n=3847)\end{array}\end{array}$ & $1987-2006$ & ART (aOR, 1.4; 95\% CI, 1.1-1.7) & 38 \\
\hline $\begin{array}{l}\text { ART births }(n=319) v \text {. spontaneous } \\
\quad \text { conception }(n=43,462)\end{array}$ & 2005 & $\begin{array}{l}\text { ART (aOR, } 1.55 ; 95 \% \text { CI, } 1.01-2.38) \\
\text { The risks of birth defects: non-ART population } \\
1.86 \% \text {, ovulation induction } 2.35 \% \text {, IUI } \\
2.89 \% \text {, and IVF } 3.45 \%\end{array}$ & 39 \\
\hline $\begin{array}{l}\text { Cases with major birth defects }(n=9584) v \text {. } \\
\text { controls }(n=4792)\end{array}$ & $1997-2003$ & $\begin{array}{l}\text { Septal heart defects (aOR, 2.1; 95\% CI, } 1.1- \\
\text { 4.0), cleft lip with or without cleft palate } \\
\text { (aOR, 2.4; 95\% CI, 1.2-5.1), oesophageal } \\
\text { atresia (aOR, 4.5; 95\% CI, 1.9-10.5) and } \\
\text { anorectal atresia (aOR, 3.7; 95\% CI, 1.5-9.1) }\end{array}$ & 40 \\
\hline $\begin{array}{l}\text { ART births }(n=33,601) v \text {. spontaneous } \\
\quad \text { conception }(n=4,421,154)\end{array}$ & $2000-2010$ & $(\mathrm{aRR}, 1.38 ; 95 \% \mathrm{CI}, 1.21-1.59)$ & 41 \\
\hline $\begin{array}{l}\text { Non-spontaneous conception }(n=264) v \\
\quad \text { spontaneous conception }(n=11240)\end{array}$ & 2010-2012 & Any defect (aRR, 0.95; 95\% CI, 0.8-1.1) & 48 \\
\hline $\begin{array}{l}\text { Spontaneous conception (time to pregnancy } \\
>12 \text { months, } n=5764) \text { and infertility } \\
\text { treatment }(n=4588) v \text {. spontaneous } \\
\text { conception (time to pregnancy } \\
\leqslant 12 \text { months, } n=50,897 \text { ) }\end{array}$ & $1997-2003$ & $\begin{array}{l}\text { Infertility (hazard ratios } 1.20,95 \% \mathrm{CI} \text {, } \\
1.07-1.35 \text { ), and infertility treatment (hazard } \\
\text { ratios } 1.39 ; 95 \% \mathrm{CI}, 1.23-1.57 \text { ). Among } \\
\text { infertile couples, infertility treatment } v \text {. natural } \\
\text { conception (hazard ratio } 2.32 ; 95 \% \mathrm{CI} \text {, } \\
1.24-4.35 \text { ) }\end{array}$ & 50 \\
\hline $\begin{array}{l}\text { ART Births }(n=4333) v \text {. spontaneous } \\
\quad \text { conception }(n=295,220)\end{array}$ & 1986-2002 & $\begin{array}{l}\text { Any defect: ART (aOR, } 1.30 ; 95 \% \text { CI, 1.16- } \\
\text { 1.45); IVF (aOR, 1.07; 95\% CI, 0.9-1.26); } \\
\text { ICSI (aOR, 1.57; 95\% CI, 1.3-1.9) }\end{array}$ & 15 \\
\hline $\begin{array}{l}\text { IVF births }(n=2930) \text {, ovarian stimulation } \\
\quad(n=3926) v \text {. controls }(n=26,489)\end{array}$ & $1996-1998$ & $\begin{array}{l}\text { Any defect: IVF (aOR, 1.30; 95\% CI, } \\
\text { 1.05-1.61); ovarian stimulation (aOR, 1.17; } \\
\text { 95\% CI, 0.97-1.41) }\end{array}$ & 52 \\
\hline $\begin{array}{l}\text { ICSI births }(n=150) v \text {. spontaneous } \\
\quad \text { conception }(n=147)\end{array}$ & $2001-2003$ & Major congenital malformation $(P<0.05)$ & 58 \\
\hline $\begin{array}{l}\text { IVF births }(n=3305) v \text {. the general } \\
\text { population }(n=1,505,724)\end{array}$ & $1982-1995$ & $\begin{array}{l}\text { Malformations (OR, 1.39; 95\%CI, 1.25-1.54), } \\
\text { and the rates of neural tube defects and } \\
\text { oesophageal atresia were higher }\end{array}$ & 94 \\
\hline
\end{tabular}

ICSI, intracytoplasmic sperm injection; CI, confidence intervals; ART, assisted reproductive technologies; aOR, adjusted odds ratio; OR, odds ratio; aRR, adjusted relative risks; IUI, intrauterine insemination.

induction had more major heart anomalies than controls conceived naturally. ${ }^{52}$ Similarly, the risks of birth defects were higher in ovulation induction $v$. natural conception, whereas the risk was even higher in IVF $v$. ovulation induction. ${ }^{39}$ Taken together, this data suggest that singletons conceived by ART procedures are at increased risk for birth defects. This is at least partly due to the underlying infertility, and parental characteristics, but may be further increased by ovulation induction and ART procedures.

\section{Growth and development in ART singleton pregnancies}

A number of studies have examined the growth patterns of ART children with conflicting results ${ }^{55-69}$ (summarized in Table 3). The majority of studies have not observed any differences in the growth of ART children $v$. naturally conceived children. For instance, recent prospective follow-up studies in the United States compared 969 singletons conceived by infertility treatment including ART and ovulation induction 
Table 3. Growth and development in assisted reproductive technologies (ART) singleton pregnancies

\begin{tabular}{|c|c|c|c|}
\hline Participants & Age & Outcomes & References \\
\hline IVF births $(n=66) v$. spontaneous conception $(n=66)$ & $12-45$ months & $\begin{array}{l}\text { The developmental indices of IVF infants were within the normal range and did not } \\
\text { differ from those of their matched controls }\end{array}$ & 56 \\
\hline IVF births $(n=258) v$. normal references & $6-13$ years & $\begin{array}{l}\text { Surgical procedures, malformation, height and weight, and school performance were } \\
\text { comparable }\end{array}$ & 69 \\
\hline $\begin{array}{l}\text { Birth from cryopreserved embryos }(n=158) \text {, IVF births }(n=160) v \text {. } \\
\text { spontaneous conception }(n=156)\end{array}$ & $0-18$ months & $\begin{array}{l}\text { Growth features, major malformations and the prevalence of chronic diseases were } \\
\text { similar }\end{array}$ & 55 \\
\hline IVF births $(n=150) v$. spontaneous conception $(n=280)$ & $0-3$ years & $\begin{array}{l}\text { Infant mortality was }>\text { two-fold higher. The risk of low height (OR, } 1.9 ; 95 \% \mathrm{CI}, 1.1- \\
\text { 3.2). Cumulative incidence of different diseases up to } 3 \text { years of age (OR, 2.1; } 95 \% \\
\mathrm{CI}, 1.3-3.3) \text { especially regarding respiratory diseases (OR, 3.1; } 95 \% \mathrm{CI}, 1.0-9.4) \\
\text { and diarrhoea (OR, 5.7; 95\% CI, 2.6-12.7). No statistically significant differences } \\
\text { were found in the psychomotor development }\end{array}$ & 64 \\
\hline ICSI births $(n=150) v$. spontaneous conception $(n=147)$ & 8 years & $\begin{array}{l}\text { Pubertal staging, neurological examination, remedial therapy or surgery or } \\
\text { hospitalization were similar }\end{array}$ & 58 \\
\hline ART births $(n=69) v$. spontaneous conception (friends and siblings, $n=71$ ) & $4-10$ years & $\begin{array}{l}\text { IVF children were taller }(P=0.001) \text {, with higher levels of serum IGF-II }(P=0.03) \text {, } \\
\text { higher IGF-I to IGF-binding protein } 3 \text { ratio }(P=0.04) \text {, higher high-density } \\
\text { lipoprotein }(P=0.02) \text {, lower triglycerides }(P=0.02) \text { and a lower total to high- } \\
\text { density lipoprotein cholesterol ratio }(P=0.01) \text {. There were no differences in body } \\
\text { composition }\end{array}$ & 65 \\
\hline $\begin{array}{l}\text { ICSI births }(n=81) v \text {. IVF births }(n=81) \text { and spontaneous conception } \\
\quad(n=85)\end{array}$ & $5-8$ years & $\begin{array}{l}\text { Outcomes of children conceived by ICSI and IVF were comparable or even more } \\
\text { positive for ICSI. Perinatal outcomes were poorer after ICSI than natural conception } \\
\text { (prematurity: } P=0.014 \text {; low birth weight: OR, 7.4; 95\% CI, } 0.9-62.5 \text { ) }\end{array}$ & 59 \\
\hline $\begin{array}{l}\text { IVF births }(n=193) v \text {. spontaneous conception from subfertile parents } \\
\quad(n=199)\end{array}$ & $0-4$ years & $\begin{array}{l}\text { Significantly lower weight, height and BMI standard deviation scores (SDSs) at } \\
3 \text { months, and weight SDS at } 6 \text { months of age, a greater gain in weight SDS } \\
(P<0.001) \text {, height SDS }(P=0.013) \text { and BMI SDS }(P=0.029) \text { during late infancy } \\
(3 \text { months to } 1 \text { year }) \text { in IVF children }\end{array}$ & 68 \\
\hline ICSI births $(n=276) v$. spontaneous conception $(n=273)$ & 5.5 years & $\begin{array}{l}\text { No relevant differences regarding physical examination, the incidence of childhood } \\
\text { illnesses, acute or chronic illnesses, accidents, and surgeries up to the age of } 5.5 \text { years. } \\
\text { However, an increased risk of undescended testicles and urogenital surgeries were } \\
\text { observed in ICSI boys }\end{array}$ & 57 \\
\hline $\begin{array}{l}\text { IVF births }(n=143) \text { and ICSI births }(n=166) v \text {. spontaneous conception } \\
\quad(n=173)\end{array}$ & $0-12$ years & $\begin{array}{l}\text { No significant differences were observed regarding head circumference, height and } \\
\text { weight between the three groups at any of the time points }\end{array}$ & 62 \\
\hline $\begin{array}{l}\text { Birth from cryopreserved embryos }(n=43) \text {, IVF births }(n=72) v \text {. } \\
\quad \text { spontaneous conception }(n=94)\end{array}$ & $3.5-11.0$ years & $\begin{array}{l}\text { IVF girls were taller, with increased insulin-like growth factor I concentrations } \\
\text { compared with controls. More favourable lipid profiles were also evident in IVF } \\
\text { children }\end{array}$ & 67 \\
\hline $\begin{array}{l}\text { ART births }(n=433) \text { and births by ovulation induction/intrauterine } \\
\text { insemination }(n=535) v \text {. spontaneous conception }(n=2471)\end{array}$ & $0-3$ years & No significant differences in growth, motor and cognitive development & 60,70 \\
\hline ART births $(n=4333) v$. spontaneous conception $(n=295,220)$ & $<5$ years & An increased risk of cerebral palsy (aOR, 2.22; 95\%CI, 1.35-3.63) & 15 \\
\hline ART births $(n=3617) v \cdot$ spontaneous conception $(n=35,848)$ & $>4$ years & An increased risk of cerebral palsy (hazard ratio $2.30 ; 95 \% \mathrm{CI}, 1.12-4.73$ ) & 80 \\
\hline $\begin{array}{l}\text { ICSI births }(n=511) \text { and IVF }(n=424) v \text {. spontaneous conception } \\
\quad(n=488)\end{array}$ & $4-6$ years & No significant differences in motor and cognitive development & 81 \\
\hline ART births $(n=33,139) v$. spontaneous conception $(n=555,728)$ & $4-13$ years & No increased risk of autism spectrum disorders & 86 \\
\hline 349 cases $v .1847$ controls & $>2$ years & No increased risk of autism spectrum disorders & 85 \\
\hline 4164 cases and 16,582 controls & $2-16$ years & No increased risk of autism spectrum disorders & 87 \\
\hline
\end{tabular}

IVF, in vitro fertilization; ICSI, intracytoplasmic sperm injection; aOR, adjusted odds ratio; OR, odds ratio; IGF, insulin-like growth factor; BMI, body mass index. 
with or without intrauterine insemination with 2471 singletons conceived naturally, and found the growth and development of children up to 3 years of age was comparable. ${ }^{60,70}$ Similar findings have been observed in ART children $v$. the general population up to 13 years of age in European countries. ${ }^{61,62,69}$ A study in the United States also reported IVF young adults exhibited normal pubertal development. ${ }^{71} \mathrm{~A}$ handful of studies have found ART children had impaired ${ }^{63,64}$ or enhanced childhood growth. ${ }^{6-67}$ Notably, some studies recruited children born prematurely, small for gestational age, with low birth weight or from multiple pregnancies, which may confound the results and few of these studies have controlled for subfertility. Ceelen $e$ a al. examined the growth data from birth to 4 years of age in a small follow-up study that included 233 IVF children aged $8-18$ years and 233 spontaneously conceived controls born to subfertile parents. They showed IVF children had significantly lower weight, height and BMI standard deviation scores (SDSs) at 3 months, and weight SDS at 6 months of age compared with controls. IVF children demonstrated a catch-up growth during late infancy ( 3 months to 1 year) $v$. controls, such that no differences were observed in weight, height and BMI after 1 year of age between groups. ${ }^{68}$ This is a small study, but potentially of concern, given evidence that rapid catch-up growth is associated with increased risk of disease later in life. ${ }^{72,73}$

A meta-analysis including four studies in singletons reported an increased risk of cerebral palsy for IVF children $v$. those conceived naturally. ${ }^{74}$ This risk may be largely due to multiple births, low birth weight and preterm births among ART children. ${ }^{75-80}$ In Australia, an increased risk of cerebral palsy was observed in ART infants overall and for ART singletons, even after adjusting for parental and fetal factors. ${ }^{15}$ Similarly, Zhu et al. ${ }^{80}$ found that ART infants had an increased risk of cerebral palsy after controlling for preterm birth and multiplicity, and there was no association between parental subfertility and the risk of cerebral palsy, indicating that the increased risk of cerebral palsy for ART infants was due to the effect of ART treatment.

No differences were observed in the cognitive and motor development in large cohort studies between ART children and controls examined at 3 or 5 years of age who were recruited in Europe ${ }^{81}$ Great Britain ${ }^{82,83}$ or the United States. ${ }^{70}$ Similarly, a systematic review of 59 studies reported that children born following ART are not at increased risk of severe cognitive impairment compared with naturally conceived children. ${ }^{84}$ There is also no increased risk of autism in singletons conceived by ART, ${ }^{85-88}$ but studies including IVF multiple births and autism spectrum disorders have shown conflicting results. ${ }^{85,87}$ In contrast, Kissin $e t a l^{89}$ found that the incidence of autism diagnosis in ART-conceived children during the first 5 years of life was higher when ICSI was used compared with IVF. Notably, Belva et al. showed that 54 ICSI-conceived adults had significantly lower sperm concentration, lower total sperm count as well as lower total motile sperm count but comparable mean levels of follicle-stimulating hormone, luteinizing hormone, testosterone and inhibin B in comparison to 57 spontaneously conceived peers, possibly reflecting inherited fertility problems. ${ }^{90,91}$ Taken together, the available data on the growth and development of ART children is generally reassuring, although an increased risk of cerebral palsy has been observed. This needs to be confirmed in large studies focussing on ART singletons born at term with normal birth weight. In addition, more follow-up studies in adults are warranted to determine if ART is associated with increased risk of impaired cognitive development and psychological adjustment, later in life.

\section{Cancer risk in ART singleton pregnancies}

Concerns are turning towards the longer-term health implications of IVF. A number of studies have been undertaken to examine the cancer risk of children conceived by ART procedures (summarized in Table 4). Most of the earlier studies demonstrate that ART procedures are not associated with increased risk of cancers. ${ }^{92-95}$ For instance, one data linkage study that included 3528 ART singletons with a median follow-up period of 4 years showed that ART children did not have a significantly increased incidence of cancer. ${ }^{92}$ Similar results have been noted in the Netherlands over an average follow-up period of 6 years $^{93}$ and in a meta-analysis of 11 cohort studies. $^{96}$

In the last decade, more studies have reported an increased risk of certain cancers in ART children. In Sweden, although there was no overall increase in cancer risk in $>16,000$ ART children compared with naturally conceived children, more cases of Langerhans histiocytosis were reported. ${ }^{97}$ After 5 years, the same group reported a moderately increased risk for all cancers in 26,692 children conceived by ART during the years 1982-2005. ${ }^{98}$ Notably, the increased cancer risk was associated with high birth weight, premature delivery and the presence of respiratory diagnoses as well as low Apgar score. ${ }^{98}$ A large retrospective Nordic population-based cohort study found ART children had an increased risk for central nervous system tumours and malignant epithelial neoplasms $v$. children born spontaneously between 1982 and 2007. ${ }^{99}$ This cohort was matched for parity, year of birth and country, and controlled for maternal age, sex, gestational age and birth defects. ${ }^{99}$ Similarly, ART was associated with an increased risk of hepatoblastoma and rhabdomyosarcoma, but not the overall risk of cancer in the United Kingdom. ${ }^{100}$ This study also controlled for confounding factors such as sex, age at diagnosis, birth weight, singleton $v$. multiple birth, parity, parental age, type of assisted conception and cause of parental infertility. A meta-analysis, published in 2013, that included 25 cohort and case-control studies reported that children born after ART are at increased risk for all cancers $(\mathrm{RR}=1.33$; 95\% CI, 1.08 $1.63)$, and specifically for leukaemias $(\mathrm{RR}=1.65 ; 95 \% \mathrm{CI}$, $1.35-2.01$ ), neuroblastomas ( $R R=4.04 ; 95 \% \mathrm{CI}, 1.24-$ $13.18)$ and retinoblastomas $(\mathrm{RR}=1.62 ; 95 \% \mathrm{CI}, 1.12-2.35)$. It should be noted that the majority of these studies did not control for confounders such as socioeconomic status, maternal smoking and perinatal health status, which may affect incidence. ${ }^{98,101}$ Further, it is unclear that whether the increased 
Table 4. Cancer risk in assisted reproductive technologies (ART) singleton pregnancies

\begin{tabular}{|c|c|c|c|}
\hline Participants & Age & Outcomes & References \\
\hline $\begin{array}{l}\text { IVF births }(n=3305) v \text {. the general population } \\
\quad(n=1,505,724)\end{array}$ & $0-14$ years & No increase in childhood cancer & 94 \\
\hline ART births $(n=3528) v$. the general population & $0-15$ years & $\begin{array}{l}\text { The standardized incidence ratio (SIR) 1.39; } \\
95 \% \text { CI, 0.62-3.09 }\end{array}$ & 92 \\
\hline IVF births $(n=332) v$. the general population & $5.2 \pm 2.8$ years & No increase in childhood cancer & 95 \\
\hline $\begin{array}{l}\text { ART births }(n=9484) v \text {. spontaneous } \\
\text { conception from subfertile parents }(n=7532)\end{array}$ & $1-14$ years & $\begin{array}{l}\text { No increased risk for childhood malignancies } \\
\quad(\text { risk ratio }=0.8 ; 95 \% \mathrm{CI}, 0.3-2.3)\end{array}$ & 93 \\
\hline $\begin{array}{l}\text { IVF births }(n=26,692) v \text {. the general } \\
\text { population }\end{array}$ & $>2$ years & $\begin{array}{l}\text { The total cancer risk estimate was } 1.42(95 \% \mathrm{CI} \text {, } \\
1.09-1.87)\end{array}$ & 98 \\
\hline $\begin{array}{l}\text { ART births }(n=61,693) v \text {. spontaneous } \\
\quad \text { conception }(n=351,536)\end{array}$ & $9.5 \pm 4.7$ years & $\begin{array}{l}\text { An increased risk was observed for central } \\
\text { nervous system tumours (adjusted HR 1.44; } \\
95 \% \text { CI, 1.01-2.05) and malignant epithelial } \\
\text { neoplasms (adjusted HR 2.03; 95\% CI, } \\
\text { 1.06-3.89) }\end{array}$ & 99 \\
\hline $\begin{array}{l}\text { IVF births }(n=62,195) v \text {. the general } \\
\text { population }\end{array}$ & $0-15$ years & $\begin{array}{l}\text { An increased risk of hepatoblastoma (SIR, 3.64; } \\
95 \% \text { CI, 1.34-7.93) and rhabdomyosarcoma } \\
\text { (SIR, 2.62; 95\% CI, 1.26-4.82) }\end{array}$ & 100 \\
\hline
\end{tabular}

IVF, in vitro fertilization; HR, hazard ratio.

risk for cancers is related to underlying subfertility of the parent, or the ART procedure itself. ${ }^{102}$ More follow-up studies are needed to determine risk in children, as well as later in life.

\section{Does ART increase the risk of chronic disease?}

The long-term health implications of IVF are under-studied. Over the past decade, speculation is increasing that individuals conceived by ART may be at risk of developing metabolic syndrome, type 2 diabetes and cardiovascular disease, later in life. ${ }^{103-107}$ To date these studies are small, and this evidence is not conclusive (summarized in Table 5). Discrepancies between studies may be due to differences in the ages investigated, study period, inclusion criteria of subjects, sample size, sampling of the comparison group, dietary intake and/or parental characteristics, as well as the ART technique employed. Ceelen et al. ${ }^{103}$ reported an increase in body fat as assessed by skinfold thickness in IVF children who were matched for BMI. Post-pubertal IVF children in this study also had a trend towards increased body fat assessed by Dual-energy X-ray absorptiometry (DXA). Importantly, the control group studied were children who were born to subfertile parents and controlled for current size, birth weight, gestational age and parental characteristics. ${ }^{103}$ Belva et al. reported pubertal ICSI singleton girls had increased central, peripheral and total adiposity assessed by circumferences, skinfolds and BMI, respectively, compared with naturally conceived controls. Furthermore, increased peripheral adiposity was observed in ICSI adolescent singleton boys with advanced pubertal stages $v$. controls. ${ }^{108}$ Conversely, one study reported no difference in fat percentage by DXA between IVF children and controls at $4-10$ years of age. ${ }^{65}$ More studies in ART adults are required to assess the obesity incidence and the amount of liver and visceral fat which is clearly associated with increased risk of type 2 diabetes and cardiovascular diseases. ${ }^{109}$

There is some suggestion that ART may also impair glucose metabolism in the offspring, potentially as a result of increased adiposity. Ceelen $e t a l .{ }^{104}$ reported IVF adolescents had elevated fasting glucose levels compared with controls, irrespective of any early life factors or parental characteristics. However, there was no significant difference in fasting insulin levels, and insulin sensitivity as measured by the homeostasis assessment model. Another study reported fasting glucose levels were higher among children aged 5-6 years old conceived through ovulation induction and ART compared with naturally conceived children from fertile couples. ${ }^{110}$ Conversely, ${ }^{105}$ there was no difference in weight, glucose, insulin, leptin, adiponectin, interleukin-6 or C-reactive protein in IVF children and controls. However, this study may be confounded by neonatal and parental factors. Another study reported IVF children were taller with significantly higher IGF1 serum levels. ${ }^{65}$ Reduced peripheral insulin sensitivity was also observed in a small cohort of IVF young adults by using gold standard assessment hyperinsulinemic-euglycemic clamp, without any significant differences in fasting glucose or insulin levels compared with naturally conceived young adults. ${ }^{107}$ However, only 14 IVF young adults were studied.

A number of studies suggest that ART may increase the risk of cardiovascular diseases. Celeen et al. ${ }^{104}$ reported that systolic and diastolic blood pressure levels were elevated in IVF children $v$. children conceived naturally from subfertile couples, after controlling for early life factors and parental characteristics. Sakka et al. ${ }^{105}$ also reported that children born by IVF had significantly higher systolic and diastolic blood pressure than controls. Elevations in blood pressure in IVF conceived individuals are not universally detected. ${ }^{111}$ 
Table 5. Metabolic risk in assisted reproductive technologies (ART) singleton pregnancies

\begin{tabular}{|c|c|c|c|c|}
\hline Participants & Age & Outcomes & Limitation & References \\
\hline $\begin{array}{l}233 \text { IVF singletons ( } 139 \text { pubertal) } v .233 \\
\text { singletons ( } 143 \text { pubertal) born from } \\
\text { subfertile parents }\end{array}$ & $8-18$ years & $\uparrow$ Body fat, $\uparrow$ blood pressure, $\uparrow$ fasting glucose & Cross-sectional study & 103,104 \\
\hline $\begin{array}{l}217 \text { ICSI singletons ( } 116 \text { boys) v. } 223 \\
\text { singletons ( } 115 \text { boys) born from fertile } \\
\text { parents }\end{array}$ & 14 years & $\uparrow$ Body fat normal blood pressure & $\begin{array}{l}\text { Body fat assessed by skinfolds; included } \\
\text { participants born prematurely or small for } \\
\text { gestation age; not controlling for subfertility }\end{array}$ & 108,111 \\
\hline $\begin{array}{l}69 \text { ART singletons ( } 35 \text { IVF, } 34 \text { ICSI) } v \text {. } \\
71 \text { singletons born from fertile parents } \\
\text { (friends and siblings) }\end{array}$ & $4-10$ years & $\begin{array}{l}\uparrow \text { HDL, } \downarrow \text { triglycerides, } \uparrow \text { IGF- } 2 \text {, } \uparrow \text { height. } \\
\text { Normal body fat and fasting glucose }\end{array}$ & $\begin{array}{l}\text { Cross-sectional study; not controlling for } \\
\text { subfertility; small sample size }\end{array}$ & 65 \\
\hline $\begin{array}{l}28 \text { ART singletons } v .220 \text { singletons born } \\
\text { from subfertile parents and } 2240 \\
\text { singletons born from fertile parents }\end{array}$ & $5-6$ years & $\uparrow$ Fasting glucose & Small sample size; not controlling for subfertility & 110 \\
\hline $\begin{array}{l}106 \text { IVF (39 pubertal) v. } 68 \text { controls } \\
\text { (30 pubertal) born from fertile parents }\end{array}$ & $4-14$ years & $\begin{array}{l}\uparrow \text { Blood pressure, } \uparrow \text { triglycerides, } \\
\uparrow T S H . \text { Normal fasting glucose }\end{array}$ & $\begin{array}{l}\text { Included participants born prematurely, small for } \\
\text { gestation age and multiples; not controlling for } \\
\text { subfertility }\end{array}$ & 105,116 \\
\hline $\begin{array}{l}14 \text { IVF } v .20 \text { controls born from fertile } \\
\text { parents }\end{array}$ & $17-26$ years & $\downarrow$ Peripheral insulin sensitivity & Small sample size; not controlling for subfertility & 107 \\
\hline $\begin{array}{l}63 \text { IVF singletons } v .79 \text { singletons born } \\
\text { from subfertile parents }\end{array}$ & 4 years & $\uparrow$ Blood pressure, $\uparrow$ body fat & Small sample size; not controlling for subfertility & 112 \\
\hline $\begin{array}{l}65 \text { ART singletons } v .57 \text { controls (friends } \\
\text { and siblings) }\end{array}$ & $7-18$ years & Systemic and pulmonary vascular dysfunction & Cross-sectional study & 106 \\
\hline 54 ART singletons $v .54$ controls (friends) & $7-18$ years & Right ventricular dysfunction & $\begin{array}{l}\text { Cross-sectional study; not controlling for } \\
\text { subfertility }\end{array}$ & 115 \\
\hline $\begin{array}{l}100 \text { ART fetuses } v .100 \text { control } \\
\text { pregnancies and } 50 \text { ART infants } v \text {. } \\
50 \text { controls }\end{array}$ & $\begin{array}{l}\text { Fetuses } \\
\quad 6 \text { months }\end{array}$ & $\begin{array}{l}\text { Cardiac and vascular remodelling at both time } \\
\text { points }\end{array}$ & Not controlling for confounding factors & 114 \\
\hline 10 IVF newborns $v .10$ controls & 2-4 weeks & Subclinical hypothyroidism & Small sample size; not controlling for subfertility & 117 \\
\hline
\end{tabular}

IVF, in vitro fertilization; ICSI, intracytoplasmic sperm injection 
There is evidence that the process of ovarian induction may be a contributing factor to increases in blood pressure since systolic blood pressure and subscapular skinfold thickness were elevated in IVF children $v$. children conceived by natural IVF (without ovarian stimulation) and subfertile couples who conceived naturally. ${ }^{12}$ Blood pressure was also higher in children born to subfertile $v$. fertile couples. ${ }^{110}$ In a more detailed investigation ${ }^{106}$ ART children displayed systemic and pulmonary vascular dysfunction, that could not be explained by subfertility or ovulation stimulation because vascular function was not altered in children conceived naturally after ovulation stimulation and in siblings of ART children who were conceived naturally. ${ }^{113}$ Further, another group conducted a prospective cohort study and found signs of cardiovascular remodelling in ART fetuses, and ART infants as compared with controls conceived spontaneously. ${ }^{114}$ Right ventricular dysfunction has also been detected in children and adolescents conceived by ART. ${ }^{115}$ Taken together, ART treatment, ovulation induction and subfertility may all contribute to adverse cardiovascular outcome in childhood, ${ }^{110}$ and further pre-clinical studies are necessary to resolve some of the discrepancies reported, as these enable better control of the confounding factors.

Few studies have examined the effects of ART on lipid metabolism. Sakka et al. ${ }^{105}$ found that IVF children had significantly higher triglycerides, without differences in total cholesterol, high-density lipoprotein (HDL), low-density lipoprotein, uric acid, apolipoprotein-A1, apolipoprotein-B or lipoprotein(a) values. ${ }^{105}$ Conversely, a group in New Zealand ${ }^{65,67}$ found more favourable lipid profiles in a prepubertal IVF children with higher HDL levels and lower triglyceride levels than in controls. More prospective follow-up studies in ART adults are required to determine if ART treatment alters lipid profiles in the offspring.

ART may also alter thyroid function. Sakka $e t a l .{ }^{116}$ reported thyroid-stimulating hormone (TSH) levels were significantly higher in 106 IVF children $v .68$ naturally conceived children aged 4-14 years. Seven IVF children, but no controls also had subclinical primary hypothyroidism. It is of note that four of these children were born prematurely with low birth weight, although statistically TSH levels was not associated with birth weight and gestational ages. Similarly, subclinical hypothyroidism was observed in 2-4-week-old IVF infants, born at term. ${ }^{117} \mathrm{~A}$ cross-sectional study in China found that the levels of thyroid hormones including T4, FT4 and TSH were significantly increased in singleton IVF $v$. naturally conceived newborns and children aged 3-10 years old. Notably, the levels of T4 and FT4 of IVF children positively correlated with maternal serum levels of oestradiol during the first trimester of pregnancy. ${ }^{118}$ Further, no statistical difference was observed between IVF children born from frozen embryo transfer and naturally conceived individuals. ${ }^{118}$ This suggests that a high oestradiol maternal environment, resulting from ovarian stimulation, may increase the risk of thyroid dysfunction in offspring born following IVF. Further study is necessary.

\section{How does ART increase the risk of adverse outcome?}

In humans, it is difficult to separate out the effects of ART procedures themselves with the underlying subfertility, paternal characteristics as well as postnatal environmental exposure. Furthermore, if increases in risk are the result of ART techniques, which of these processes increase risk? Animal models suggest that ART procedures contribute to altered fetal and placental growth and development. ${ }^{19}$ The developmental origins of health and disease hypothesis ${ }^{120}$ proposes that suboptimal periconceptional and perinatal environment can impair fetal and postnatal growth, followed by catch-up growth, predisposes offspring to increased risk of developing hypertension, obesity, type 2 diabetes and coronary heart disease in later life. ${ }^{121-123}$ Epigenetic is likely to be the reprogramming mechanism, but there may be other contributing factors including transcription changes, oxidative stress and mitochondrial dysfunction, and endoplasmic reticulum stress as reviewed elsewhere. ${ }^{124}$

Epigenetics is defined as heritable changes in gene expression without alterations in DNA sequence. ${ }^{125}$ Epigenetic modifications, including DNA methylation, histone modifications, micro-RNAs and higher-order packaging of DNA around nucleosomes, regulate the temporal and spatial gene expression patterns and are essential in embryonic, fetal and postnatal development. ${ }^{126}$ DNA methylation is the most widely studied epigenetic mechanism and occurs through the enzymatic addition of a methyl group to the carbon-5 position of the cytosine of the cytosine-phosphate-guanine dinucleotide sequence. The methyl group interferes with the binding of particular transcription factors to DNA and attracts methyl-binding proteins that also regulate transcriptional repression. ${ }^{127}$ Hence, gene expression is generally inhibited by DNA methylation, but is activated by DNA demethylation. ${ }^{128}$ DNA methylation also contributes to the preservation of chromosomal integrity and the inactivation of X-chromosome. ${ }^{129}$ There are two waves of DNA methylation and demethylation during gametogenesis and early preimplantation, ${ }^{130}$ thus periconceptual manipulation of oocyte or blastocyst during IVF and ICSI treatment may impair the establishment of the DNA methylation in gametes and/or with the maintenance of DNA methylation within preimplantation embryos. ${ }^{129}$

In humans, there is evidence that ART procedures may alter epigenetic modifications during the preimplantation period of development. A high frequency of imprinted methylation errors was observed in ART human preimplantation embryos. ${ }^{131}$ Altered DNA methylation and/or gene expression of a number of genes in the fetus, cord blood, placenta, neonatal bloodspots and buccal cell have been reported in ART children. ${ }^{132-139}$ Notably, some of these genes whose expression altered by ART have been implicated in imprinting diseases and metabolic disorders such as obesity and type 2 diabetes. Song et al. ${ }^{133}$ showed ART itself results in significant differences in placental DNA methylation levels by using donor 
oocyte from fertile young women compared with fertile control groups. Another study suggests DNA methylation levels of 23 genes can explain around $80 \%$ of the variance in infant birth weight and six of these are associated with growth phenotypes in human or mouse models. ${ }^{140}$ Therefore, altered DNA methylation in ART offspring may contributes to low birth weight which is a marker of impaired fetal growth and adverse long-term health outcomes.

Animal models also support that ART alters epigenetic modifications in preimplantation embryos and offspring, thereby altering embryonic growth, fetal and placental growth, growth trajectory, increases risk of metabolic and cardiovascular diseases later in life, and shortens lifespan. ${ }^{107,141-149}$ Metabolic profiling in mice serum and microarray analysis of pancreatic islets and insulin-sensitive tissues (liver, skeletal muscle and adipose tissue) indicated systemic oxidative stress and mitochondrial dysfunction, which is associated with increased expression of thioredoxin-interacting protein (TXNIP) and enrichment for $\mathrm{H} 4$ acetylation at the Txnip promoter in blastocysts and adipose tissue in adult mice. ${ }^{148}$ As TXNIP plays an important role in regulating peripheral glucose metabolism and integrating cellular nutritional and oxidative states with metabolic response, the data suggest that IVF results in epigenetic and gene expression changes in blastocysts that persist in adulthood. ${ }^{148}$ Rexhaj et al. ${ }^{149}$ reported that ART mice offspring show endothelial dysfunction, increased arterial stiffness and arterial hypertension as well as shortened life span fed with a high-fat diet. Moreover, male ART mice transmit vascular dysfunction to their progeny and the methylation of imprinted genes such as H19 in the aorta is altered in ART mice and their progeny. Further, ART mice display increased DNA methylation of the promoter of the eNOS gene, decreased $e N O S$ expression in the aorta and decreased plasma nitric oxide concentration. Importantly, all these alterations can be normalized by administration of the deacetylase inhibitor butyrate or addition of antioxidant melatonin to culture media, suggesting that altered epigenetic modification by ART causes vascular dysfunction in mice. ${ }^{149,150}$

Placenta plays an important role in fetal development by transporting nutrients and oxygen, adapting morphologically and functionally to adverse environmental stress and minimizing their impact on the fetus. ${ }^{151,152}$ Placenta size can predict cardiovascular diseases and insulin resistance. ${ }^{153,154}$ ART may also impair placental development and function and thus fetal growth in utero. ${ }^{141,142,155,156}$ Increased placental thickness and placental haematomas as well as pathological findings were reported in ART pregnancies. ${ }^{157-159}$ IVF impairs placental nutrient transport and metabolism in mice. ${ }^{141,144,156}$ Placental weight and placental:fetal weight ratio was significantly higher in ART pregnancies than in naturally conceived pregnancies in humans and mouse models. ${ }^{119,155,156,160,161}$ This was associated with reduced methylation levels and altered genomic imprinting and developmental gene expression by ART treatment in the placenta in mice and humans. ${ }^{132,138,141,142,144,155}$ These altered DNA methylation levels may impair a number of biological processes and functions during IVF placentation, including actin cytoskeleton organization, haematopoiesis, placental growth and vascularization, energy metabolism and nutrient transport. ${ }^{144,162}$ Improper adaptive responses of placenta throughout pregnancy may result in adverse outcomes such as abortion, preeclampsia or intra-uterine growth restriction. ${ }^{162}$ Although successful placental adaptation leads to normal progress of the pregnancy, the memory of epigenetic adaptation mechanisms established during pregnancy increases the risk of developing metabolic diseases later in life. ${ }^{162}$ Taken together, impaired placental function and development due to altered DNA methylation may play a key role underlying the adverse outcomes in ART offspring. However, more studies are needed to examine whether other epigenetic mechanisms such as histone modifications and micro-RNAs during the development of preimplantation embryos are altered by ART.

\section{Future directions to improve health of ART children}

The perinatal outcomes in children born after ART have improved over time, mainly as a result of single embryo transfer and frozen thaw embryo transfer. ${ }^{163,164}$ As already practiced in many countries, single embryo transfer clearly reduces many of the risks associated with ART procedures, including improved perinatal outcomes, without compromizing live birth rates. ${ }^{165,166}$ The impact of hormone stimulation on perinatal and longer-term outcomes is under increasing scrutiny. The available evidence indicates that frozen embryo transfer may improve outcomes for both patients, and especially women with polycystic ovary syndrome and infants. ${ }^{24,167}$ However, large well-controlled trials to determine if freeze-all protocols have benefits to the general infertile population and the later metabolic health in ART children are still needed. Further pre-clinical and large epidemiological studies from around the globe, that collect data to control for as many potential confounders as possible, are needed to compare ART techniques including frozen embryo transfer, stimulated $v$. unstimulated IVF cycles and the embryo culture lengths for not only the optimal perinatal outcomes, but for long-term health.

\section{Conclusion}

Concerns remain over the health and development of ART babies. Multiple pregnancies, due to multiple embryo transfer, increase the health risks, but ART singletons are also at increased risk of adverse obstetric and perinatal outcomes, increased risk for birth defects as compared with singletons conceived spontaneously. Further studies are needed to confirm if ART singletons have an increased risk of cancers, and cerebral palsy. Although accumulating data suggests that individuals conceived by ART may also have an increased risk of ageing-related chronic metabolic disorders, the evidence to date is obtained from pre-clinical studies, or small human cohorts. Thus large scale, well-controlled epidemiological studies are necessary. Greater work is also necessary to identify whether the increase in obstetric, perinatal and health impacts observed in 
ART children are the direct result of the ART procedure itself, or a result of the underlying subfertility of the parents. Although evidence suggests that altered DNA methylation and impaired placental development may contribute to the adverse outcomes in ART children, more studies are needed to examine whether altered epigenetic regulations are the underlying mechanism or the consequence of aberrant embryo development. As genetics and many parental characteristics cannot be altered, careful further study to identify the optimal ART procedures that maximize both perinatal and long-term health outcomes are necessary.

\section{Acknowledgement}

None.

\section{Financial Support}

LKH is supported by Australia Research Council Futures Fellowship.

\section{Conflicts of Interest}

None.

\section{References}

1. Zegers-Hochschild F, Adamson GD, de Mouzon J, et al. The International Committee for Monitoring Assisted Reproductive Technology (ICMART) and the World Health Organization (WHO) revised glossary on ART terminology, 2009. Hum Reprod. 2009; 24, 2683-2687.

2. Ferraretti AP, Goossens V, Kupka M, et al. Assisted reproductive technology in Europe, 2009: results generated from European registers by ESHRE. Hum Reprod. 2013; 28, 2318-2331.

3. Schieve LA, Rasmussen SA, Buck GM, et al. Are children born after assisted reproductive technology at increased risk for adverse health outcomes? Obstet Gynecol. 2004; 103, 1154-1163.

4. Sutcliffe AG, Ludwig M. Outcome of assisted reproduction. Lancet. 2007; 370, 351-359.

5. Allen VM, Wilson RD, Cheung A. Pregnancy outcomes after assisted reproductive technology. J Obstet Gynaecol Can. 2006; 28, 220-250.

6. Ludwig AK, Sutcliffe AG, Diedrich K, et al. Post-neonatal health and development of children born after assisted reproduction: a systematic review of controlled studies. Eur J Obstet Gynecol Reprod Biol. 2006; 127, 3-25.

7. Chung K, Coutifaris C, Chalian R, et al. Factors influencing adverse perinatal outcomes in pregnancies achieved through use of in vitro fertilization. Fertil Steril. 2006; 86, 1634-1641.

8. Wisborg K, Ingerslev HJ, Henriksen TB. IVF and stillbirth: a prospective follow-up study. Hum Reprod. 2010; 25, 1312-1316.

9. Basatemur E, Sutcliffe A. Follow-up of children born after ART. Placenta. 2008; 29(Suppl. B), 135-140.

10. Hart R, Norman RJ. The longer-term health outcomes for children born as a result of IVF treatment: part I - general health outcomes. Hum Reprod Update. 2013; 19, 232-243.
11. Pinborg A, Wennerholm UB, Romundstad LB, et al. Why do singletons conceived after assisted reproduction technology have adverse perinatal outcome? Systematic review and meta-analysis. Hum Reprod Update. 2013; 19, 87-104.

12. Henningsen AK, Pinborg A, Lidegaard O, et al. Perinatal outcome of singleton siblings born after assisted reproductive technology and spontaneous conception: Danish national siblingcohort study. Fertil Steril. 2011; 95, 959-963.

13. Pandey S, Shetty A, Hamilton M, et al. Obstetric and perinatal outcomes in singleton pregnancies resulting from IVF/ICSI: a systematic review and meta-analysis. Hum Reprod Update. 2012; 18, 485-503.

14. Helmerhorst FM, Perquin DA, Donker D, et al. Perinatal outcome of singletons and twins after assisted conception: a systematic review of controlled studies. BMJ. 2004; 328, 261.

15. Davies MJ, Moore VM, Willson KJ, et al. Reproductive technologies and the risk of birth defects. NEnglJ Med. 2012; 366, 1803-1813.

16. McDonald SD, Han Z, Mulla S, et al. Preterm birth and low birth weight among in vitro fertilization singletons: a systematic review and meta-analyses. Eur J Obstet Gynecol Reprod Biol. 2009; 146, 138-148.

17. Buckett WM, Chian RC, Holzer H, et al. Obstetric outcomes and congenital abnormalities after in vitro maturation, in vitro fertilization, and intracytoplasmic sperm injection. Obstet Gynecol. 2007; 110, 885-891.

18. Pinborg A, Lidegaard O, Freiesleben N, et al. Vanishing twins: a predictor of small-for-gestational age in IVF singletons. Hum Reprod. 2007; 22, 2707-2714.

19. Pinborg A, Lidegaard O, la Cour Freiesleben N, et al. Consequences of vanishing twins in IVF/ICSI pregnancies. Hum Reprod. 2005; 20, 2821-2829.

20. Basso O, Baird DD. Infertility and preterm delivery, birthweight, and caesarean section: a study within the Danish National Birth Cohort. Hum Reprod. 2003; 18, 2478-2484.

21. Zhu JL, Obel C, Hammer Bech B, et al. Infertility, infertility treatment, and fetal growth restriction. Obstet Gynecol. 2007; 110, 1326-1334.

22. Raatikainen K, Kuivasaari-Pirinen P, Hippelainen M, et al. Comparison of the pregnancy outcomes of subfertile women after infertility treatment and in naturally conceived pregnancies. Hum Reprod. 2012; 27, 1162-1169.

23. Seggers J, Pontesilli M, Ravelli AC, et al. Effects of in vitro fertilization and maternal characteristics on perinatal outcomes: a population-based study using siblings. Fertil Steril. 2016; 105, 590-598.e2.

24. Chen ZJ, Shi Y, Sun Y, et al. Fresh versus frozen embryos for infertility in the polycystic ovary syndrome. N Engl J Med. 2016; 375, 523-533.

25. Maheshwari A, Pandey S, Shetty A, et al. Obstetric and perinatal outcomes in singleton pregnancies resulting from the transfer of frozen thawed versus fresh embryos generated through in vitro fertilization treatment: a systematic review and meta-analysis. Fertil Steril. 2012; 98, 368-377.e1-9.

26. Mak W, Kondapalli LA, Celia G, et al. Natural cycle IVF reduces the risk of low birthweight infants compared with conventional stimulated IVF. Hum Reprod. 2016; 31, 789-794.

27. Sunkara SK, LaMarca A, Polyzos NP, et al. Live birth and perinatal outcomes following stimulated and unstimulated IVF: analysis of over two decades of a nationwide data. Hum Reprod, 2016. 
28. Wirleitner B, Vanderzwalmen P, Stecher A, et al. Individual demands of human embryos on IVF culture medium: influence on blastocyst development and pregnancy outcome. Reprod BioMed Online. 2010; 21, 776-782.

29. Vergouw CG, Kostelijk EH, Doejaaren E, et al. The influence of the type of embryo culture medium on neonatal birthweight after single embryo transfer in IVF. Hum Reprod. 2012; 27, 2619-2626.

30. Dumoulin JC, Land JA, Van Montfoort AP, et al. Effect of in vitro culture of human embryos on birthweight of newborns. Hum Reprod. 2010; 25, 605-612.

31. Glujovsky D, Farquhar C, Quinteiro Retamar AM, et al. Cleavage stage versus blastocyst stage embryo transfer in assisted reproductive technology. Cochrane Database Syst Rev. 2016; (6), CD002118.

32. Dar S, Lazer T, Shah PS, et al. Neonatal outcomes among singleton births after blastocyst versus cleavage stage embryo transfer: a systematic review and meta-analysis. Hum Reprod Update. 2014; 20, 439-448.

33. Bonduelle M, Liebaers I, Deketelaere V, et al. Neonatal data on a cohort of 2889 infants born after ICSI (1991-1999) and of 2995 infants born after IVF (1983-1999). Hum Reprod. 2002; 17, 671-694.

34. Bonduelle M, Wilikens A, Buysse A, et al. Prospective follow-up study of 877 children born after intracytoplasmic sperm injection (ICSI), with ejaculated epididymal and testicular spermatozoa and after replacement of cryopreserved embryos obtained after ICSI. Hum Reprod. 1996; 11(Suppl. 4), 131-155, discussion 156-9.

35. Hansen M, Kurinczuk JJ, Bower C, et al. The risk of major birth defects after intracytoplasmic sperm injection and in vitro fertilization. N Engl J Med. 2002; 346, 725-730.

36. Merlob P, Sapir O, Sulkes J, et al. The prevalence of major congenital malformations during two periods of time, 1986-1994 and 1995-2002 in newborns conceived by assisted reproduction technology. Eur J Med Genet. 2005; 48, 5-11.

37. Gutarra-Vilchez R, Santamarina-Rubio E, Salvador J, et al. Birth defects in medically assisted reproduction pregnancies in the city of Barcelona. Prenat Diagn. 2014; 34, 327-334.

38. Tararbit K, Houyel L, Bonnet D, et al. Risk of congenital heart defects associated with assisted reproductive technologies: a population-based evaluation. Eur Heart J. 2011; 32, 500-508.

39. El-Chaar D, Yang Q, Gao J, et al. Risk of birth defects increased in pregnancies conceived by assisted human reproduction. Fertil Steril. 2009; 92, 1557-1561.

40. Reefhuis J, Honein MA, Schieve LA, et al. Assisted reproductive technology and major structural birth defects in the United States. Hum Reprod. 2009; 24, 360-366.

41. Boulet SL, Kirby RS, Reefhuis J, et al. Assisted reproductive technology and birth defects among liveborn infants in Florida, Massachusetts, and Michigan, 2000-2010. JAMA Pediatr. 2016; 170, e154934.

42. Rimm AA, Katayama AC, Diaz M, et al. A meta-analysis of controlled studies comparing major malformation rates in IVF and ICSI infants with naturally conceived children. J Assist Reprod Genet. 2004; 21, 437-443.

43. Hansen M, Bower C, Milne E, et al. Assisted reproductive technologies and the risk of birth defects - a systematic review. Hum Reprod. 2005; 20, 328-338.

44. McDonald SD, Murphy K, Beyene J, et al. Perinatel outcomes of singleton pregnancies achieved by in vitro fertilization: a systematic review and meta-analysis. J Obstet Gynaecol Can. 2005; 27, 449-459.

45. Wen J, Jiang J, Ding C, et al. Birth defects in children conceived by in vitro fertilization and intracytoplasmic sperm injection: a meta-analysis. Fertil Steril. 2012; 97, 1331-1337.e1-4.

46. Hansen M, Kurinczuk JJ, Milne E, et al. Assisted reproductive technology and birth defects: a systematic review and metaanalysis. Hum Reprod Update. 2013; 19, 330-353.

47. Qin J, Sheng X, Wang H, et al. Assisted reproductive technology and risk of congenital malformations: a meta-analysis based on cohort studies. Arch Gynecol Obstet. 2015; 292, 777-798.

48. Parazzini F, Cipriani S, Bulfoni G, et al. The risk of birth defects after assisted reproduction. J Assist Reprod Genet. 2015; 32, 379-385.

49. Ge ZJ, Schatten H, Zhang CL, et al. Oocyte ageing and epigenetics. Reproduction. 2015; 149, R103-R114.

50. Zhu JL, Basso O, Obel C, et al. Infertility, infertility treatment, and congenital malformations: Danish national birth cohort. BMJ. 2006; 333, 679.

51. Massaro PA, MacLellan DL, Anderson PA, et al. Does intracytoplasmic sperm injection pose an increased risk of genitourinary congenital malformations in offspring compared to in vitro fertilization? A systematic review and meta-analysis. J Urol. 2015; 193(Suppl.), 1837-1842.

52. Klemetti R, Gissler M, Sevon T, et al. Children born after assisted fertilization have an increased rate of major congenital anomalies. Fertil Steril. 2005; 84, 1300-1307.

53. Santos MA, Kuijk EW, Macklon NS. The impact of ovarian stimulation for IVF on the developing embryo. Reproduction. 2010; 139, 23-34.

54. Vialard F, Boitrelle F, Molina-Gomes D, et al. Predisposition to aneuploidy in the oocyte. Cytogenet Genome Res. 2011; 133, 127-135.

55. Wennerholm UB, Albertsson-Wikland K, Bergh C, et al. Postnatal growth and health in children born after cryopreservation as embryos. Lancet. 1998; 351, 1085-1090.

56. Brandes JM, Scher A, Itzkovits J, et al. Growth and development of children conceived by in vitro fertilization. Pediatrics. 1992; 90 , 424-429.

57. Ludwig AK, Katalinic A, Thyen U, et al. Physical health at 5.5 years of age of term-born singletons after intracytoplasmic sperm injection: results of a prospective, controlled, singleblinded study. Fertil Steril. 2009; 91, 115-124.

58. Belva F, Henriet S, Liebaers I, et al. Medical outcome of 8-yearold singleton ICSI children (born $>$ or $=32$ weeks' gestation) and a spontaneously conceived comparison group. Hum Reprod. 2007; 22, 506-515.

59. Knoester M, Helmerhorst FM, Vandenbroucke JP, et al. Perinatal outcome, health, growth, and medical care utilization of 5- to 8 -year-old intracytoplasmic sperm injection singletons. Fertil Steril. 2008; 89, 1133-1146.

60. Yeung EH, Sundaram R, Bell EM, et al. Infertility treatment and children's longitudinal growth between birth and 3 years of age. Hum Reprod. 2016; 31, 1621-1628.

61. Bonduelle M, Wennerholm UB, Loft A, et al. A multi-centre cohort study of the physical health of 5-year-old children conceived after intracytoplasmic sperm injection, in vitro fertilization and natural conception. Hum Reprod. 2005; 20, 413-419.

62. Basatemur E, Shevlin M, Sutcliffe A. Growth of children conceived by IVF and ICSI up to 12 years of age. Reprod Biomed Online. 2010; 20, 144-149. 
63. Kai CM, Main KM, Andersen AN, et al. Serum insulin-like growth factor-I (IGF-I) and growth in children born after assisted reproduction. J Clin Endocrinol Metab. 2006; 91, 4352-4360.

64. Koivurova S, Hartikainen AL, Sovio U, et al. Growth, psychomotor development and morbidity up to 3 years of age in children born after IVF. Hum Reprod. 2003; 18, 2328-2336.

65. Miles HL, Hofman PL, Peek J, et al. In vitro fertilization improves childhood growth and metabolism. J Clin Endocrinol Metab. 2007; 92, 3441-3445.

66. Makhoul IR, Tamir A, Bader D, et al. In vitro fertilisation and use of ovulation enhancers may both influence childhood height in very low birthweight infants. Arch Dis Child Fetal Neonatal Ed. 2009; 94, F355-F359.

67. Green MP, Mouat F, Miles HL, et al. Phenotypic differences in children conceived from fresh and thawed embryos in in vitro fertilization compared with naturally conceived children. Fertil Steril. 2013; 99, 1898-1904.

68. Ceelen M, van Weissenbruch MM, Prein J, et al. Growth during infancy and early childhood in relation to blood pressure and body fat measures at age 8-18 years of IVF children and spontaneously conceived controls born to subfertile parents. Hum Reprod. 2009; 24, 2788-2795.

69. Olivennes F, Kerbrat V, Rufat P, et al. Follow-up of a cohort of 422 children aged 6 to 13 years conceived by in vitro fertilization. Fertil Steril. 1997; 67, 284-289.

70. Yeung EH, Sundaram R, Bell EM, et al. Examining infertility treatment and early childhood development in the upstate KIDS study. JAMA Pediatr. 2016; 170, 251-258.

71. Beydoun HA, Sicignano M, Beydoun MA, et al. Pubertal development of the first cohort of young adults conceived by in vitro fertilization in the United States. Fertil Steril. 2011; 95, 528-533.

72. Ong KK, Loos RJ. Rapid infancy weight gain and subsequent obesity: systematic reviews and hopeful suggestions. Acta Paediatr. 2006; 95, 904-908.

73. Ekelund U, Ong KK, Linne Y, et al. Association of weight gain in infancy and early childhood with metabolic risk in young adults. J Clin Endocrinol Metab. 2007; 92, 98-103.

74. Hvidtjorn D, Schieve L, Schendel D, et al. Cerebral palsy, autism spectrum disorders, and developmental delay in children born after assisted conception: a systematic review and meta-analysis. Arch Pediatr Adolesc Med. 2009; 163, 72-83.

75. Ericson A, Nygren KG, Olausson PO, et al. Hospital care utilization of infants born after IVF. Hum Reprod. 2002; 17, 929-932.

76. Klemetti R, Sevon T, Gissler M, et al. Health of children born as a result of in vitro fertilization. Pediatrics. 2006; 118, 1819-1827.

77. Stromberg B, Dahlquist G, Ericson A, et al. Neurological sequelae in children born after in-vitro fertilisation: a populationbased study. Lancet. 2002; 359, 461-465.

78. Hvidtjorn D, Grove J, Schendel DE, et al. Cerebral palsy among children born after in vitro fertilization: the role of preterm delivery - a population-based, cohort study. Pediatrics. 2006; 118, 475-482.

79. Hvidtjorn D, Grove J, Schendel D, et al. Multiplicity and early gestational age contribute to an increased risk of cerebral palsy from assisted conception: a population-based cohort study. Hum Reprod. 2010; 25, 2115-2123.
80. Zhu JL, Hvidtjorn D, Basso O, et al. Parental infertility and cerebral palsy in children. Hum Reprod. 2010; 25, 3142-3145.

81. Ponjaert-Kristoffersen I, Bonduelle M, Barnes J, et al. International collaborative study of intracytoplasmic sperm injection-conceived, in vitro fertilization-conceived, and naturally conceived 5-year-old child outcomes: cognitive and motor assessments. Pediatrics. 2005; 115, e283-e289.

82. Carson C, Kurinczuk JJ, Sacker A, et al. Cognitive development following ART: effect of choice of comparison group, confounding and mediating factors. Hum Reprod. 2010; 25, 244-252.

83. Carson C, Kelly Y, Kurinczuk JJ, et al. Effect of pregnancy planning and fertility treatment on cognitive outcomes in children at ages 3 and 5: longitudinal cohort study. BMJ. 2011; $343, \mathrm{~d} 4473$.

84. Middelburg KJ, Heineman MJ, Bos AF, et al. Neuromotor, cognitive, language and behavioural outcome in children born following IVF or ICSI - a systematic review. Hum Reprod Update. 2008; 14, 219-231.

85. Grether JK, Qian Y, Croughan MS, et al. Is infertility associated with childhood autism? J Autism Dev Disord. 2013; 43, 663-672.

86. Hvidtjorn D, Grove J, Schendel D, et al. Risk of autism spectrum disorders in children born after assisted conception: a populationbased follow-up study. J Epidemiol Community Health. 2011; 65, 497-502.

87. Lehti V, Brown AS, Gissler M, et al. Autism spectrum disorders in IVF children: a national case-control study in Finland. Hum Reprod. 2013; 28, 812-818.

88. Lyall K, Baker A, Hertz-Picciotto I, et al. Infertility and its treatments in association with autism spectrum disorders: a review and results from the CHARGE study. Int J Environ Res Public Health. 2013; 10, 3715-3734.

89. Kissin DM, Zhang Y, Boulet SL, et al. Association of assisted reproductive technology (ART) treatment and parental infertility diagnosis with autism in ART-conceived children. Hum Reprod. 2015; 30, 454-465.

90. Belva F, Bonduelle M, Roelants M, et al. Semen quality of young adult ICSI offspring: the first results. Hum Reprod. 2016; 31, 2811-2820.

91. Belva F, Roelants M, De Schepper J, et al. Reproductive hormones of ICSI-conceived young adult men: the first results. Hum Reprod. 2017; 32, 439-446.

92. Bruinsma F, Venn A, Lancaster P, et al. Incidence of cancer in children born after in-vitro fertilization. Hum Reprod. 2000; 15, 604-607.

93. Klip H, Burger CW, de Kraker J, et al. Risk of cancer in the offspring of women who underwent ovarian stimulation for IVF. Hum Reprod. 2001; 16, 2451-2458.

94. Bergh T, Ericson A, Hillensjo T, et al. Deliveries and children born after in-vitro fertilisation in Sweden 1982-95: a retrospective cohort study. Lancet. 1999; 354, 1579-1585.

95. Lerner-Geva L, Toren A, Chetrit A, et al. The risk for cancer among children of women who underwent in vitro fertilization. Cancer. 2000; 88, 2845-2847.

96. Raimondi S, Pedotti P, Taioli E. Meta-analysis of cancer incidence in children born after assisted reproductive technologies. Br J Cancer. 2005; 93, 1053-1056.

97. Kallen B, Finnstrom O, Nygren KG, et al. In vitro fertilization in Sweden: child morbidity including cancer risk. Fertil Steril. 2005; 84, 605-610. 
98. Kallen B, Finnstrom O, Lindam A, et al. Cancer risk in children and young adults conceived by in vitro fertilization. Pediatrics. 2010; 126, 270-276.

99. Sundh KJ, Henningsen AK, Kallen K, et al. Cancer in children and young adults born after assisted reproductive technology: a Nordic cohort study from the Committee of Nordic ART and Safety (CoNARTaS). Hum Reprod. 2014; 29, 2050-2057.

100. Williams CL, Bunch KJ, Stiller CA, et al. Cancer risk among children born after assisted conception. $N$ Engl J Med. 2013; 369, 1819-1827.

101. Schmidt LS, Schuz J, Lahteenmaki P, et al. Fetal growth, preterm birth, neonatal stress and risk for CNS tumors in children: a Nordic population- and register-based casecontrol study. Cancer Epidemiol Biomarkers Prev. 2010; 19, 1042-1052.

102. Hargreave M, Jensen A, Toender A, et al. Fertility treatment and childhood cancer risk: a systematic meta-analysis. Fertil Steril. 2013; 100, 150-161.

103. Ceelen M, et al. Body composition in children and adolescents born after in vitro fertilization or spontaneous conception. J Clin Endocrinol Metab. 2007; 92, 3417-3423.

104. Ceelen M, van Weissenbruch MM, Roos JC, et al. Cardiometabolic differences in children born after in vitro fertilization: follow-up study. J Clin Endocrinol Metab. 2008; 93, 1682-1688.

105. Sakka SD, Loutradis D, Kanaka-Gantenbein C, et al. Absence of insulin resistance and low-grade inflammation despite early metabolic syndrome manifestations in children born after in vitro fertilization. Fertil Steril. 2010; 94, 1693-1699.

106. Scherrer U, Rimoldi SF, Rexhaj E, et al. Systemic and pulmonary vascular dysfunction in children conceived by assisted reproductive technologies. Circulation. 2012; 125, 1890-1896.

107. Chen M, Wu L, Zhao J, et al. Altered glucose metabolism in mouse and humans conceived by IVF. Diabetes. 2014; 63, 3189-3198.

108. Belva F, Painter R, Bonduelle M, et al. Are ICSI adolescents at risk for increased adiposity? Hum Reprod. 2012; 27, 257-264.

109. van Harmelen V, Eriksson A, Astrom G, et al. Vascular peptide endothelin-1 links fat accumulation with alterations of visceral adipocyte lipolysis. Diabetes. 2008; 57, 378-386.

110. Pontesilli M, Painter RC, Grooten IJ, et al. Subfertility and assisted reproduction techniques are associated with poorer cardiometabolic profiles in childhood. Reprod Biomed Online. 2015; 30, 258-267.

111. Belva F, Roelants M, De Schepper J, et al. Blood pressure in ICSI-conceived adolescents. Hum Reprod. 2012; 27, 3100-3108.

112. La Bastide-Van Gemert S, Seggers J, Haadsma ML, et al. Is ovarian hyperstimulation associated with higher blood pressure in 4-year-old IVF offspring? Part II: an explorative causal inference approach. Hum Reprod, 2013.

113. Sakka SD, Margeli A, Loutradis D, et al. Gender dimorphic increase in RBP-4 and NGAL in children born after IVF: an epigenetic phenomenon? Eur J Clin Invest. 2013; 43, 439-448.

114. Valenzuela-Alcaraz B, Crispi F, Bijnens B, et al. Assisted reproductive technologies are associated with cardiovascular remodeling in utero that persists postnatally. Circulation. 2013; 128, 1442-1450.
115. von Arx R, Allemann Y, Sartori C, et al. Right ventricular dysfunction in children and adolescents conceived by assisted reproductive technologies. J Appl Physiol (1985). 2015; 118, 1200-1206.

116. Sakka SD, Malamitsi-Puchner A, Loutradis D, et al. Euthyroid hyperthyrotropinemia in children born after in vitro fertilization. J Clin Endocrinol Metab. 2009; 94, 1338-1341.

117. Onal H, Ercan O, Adal E, et al. Subclinical hypothyroidism in in vitro fertilization babies. Acta Paediatr. 2012; 101, e248-e252.

118. Lv PP, Meng Y, Lv M, et al. Altered thyroid hormone profile in offspring after exposure to high estradiol environment during the first trimester of pregnancy: a cross-sectional study. $B M C$ Med. 2014; 12, 240.

119. Bloise E, Feuer SK, Rinaudo PF. Comparative intrauterine development and placental function of ART concepti: implications for human reproductive medicine and animal breeding. Hum Reprod Update. 2014; 20, 822-839.

120. Barker DJ. The developmental origins of adult disease. Eur J Epidemiol. 2003; 18, 733-736.

121. Eriksson JG, Forsen T, Tuomilehto J, et al. Effects of size at birth and childhood growth on the insulin resistance syndrome in elderly individuals. Diabetologia. 2002; 45, 342-348.

122. Barker DJ, Winter PD, Osmond C, et al. Weight in infancy and death from ischaemic heart disease. Lancet. 1989; 2, 577-580.

123. Forsen T, Eriksson J, Tuomilehto J, et al. The fetal and childhood growth of persons who develop type 2 diabetes. Ann Intern Med. 2000; 133, 176-182.

124. Rinaudo P, Wang E. Fetal programming and metabolic syndrome. Annu Rev Physiol. 2012; 74, 107-130.

125. Waddington CH. The epigenotype. Endeavour. 1942; 1, 18-20.

126. Le Bouc Y, Rossignol S, Azzi S, et al. Epigenetics, genomic imprinting and assisted reproductive technology. Ann Endocrinol (Paris). 2010; 71, 237-238.

127. Swales AK, Spears N. Genomic imprinting and reproduction. Reproduction. 2005; 130, 389-399.

128. Dennis C. Epigenetics and disease: altered states. Nature. 2003; 421, 686-688.

129. Laprise SL. Implications of epigenetics and genomic imprinting in assisted reproductive technologies. Mol Reprod Dev. 2009; 76, 1006-1018.

130. Reik W, Walter J. Genomic imprinting: parental influence on the genome. Nat Rev Genet. 2001; 2, 21-32.

131. White CR, Denomme MM, Tekpetey FR, et al. High frequency of imprinted methylation errors in human preimplantation embryos. Sci Rep. 2015; 5, 17311.

132. Katari S, Turan N, Bibikova M, et al. DNA methylation and gene expression differences in children conceived in vitro or in vivo. Hum Mol Genet. 2009; 18, 3769-3778.

133. Song S, Ghosh J, Mainigi M, et al. DNA methylation differences between in vitro- and in vivo-conceived children are associated with ART procedures rather than infertility. Clin Epigenetics. 2015; 7, 41.

134. Whitelaw N, Bhattacharya S, Hoad G, et al. Epigenetic status in the offspring of spontaneous and assisted conception. Hum Reprod. 2014; 29, 1452-1458.

135. Estill MS, Bolnick JM, Waterland RA, et al. Assisted reproductive technology alters deoxyribonucleic acid methylation profiles in bloodspots of newborn infants. Fertil Steril. 2016; 106, 629-639.e10. 
136. Lou H, Le F., Zheng Y, et al. Assisted reproductive technologies impair the expression and methylation of insulin-induced gene 1 and sterol regulatory element-binding factor 1 in the fetus and placenta. Fertil Steril. 2014; 101, 974-980.e2.

137. Nelissen EC, Dumoulin JC, Daunay A, et al. Placentas from pregnancies conceived by IVF/ICSI have a reduced DNA methylation level at the $\mathrm{H} 19$ and MEST differentially methylated regions. Hum Reprod. 2013; 28, 1117-1126.

138. Turan N, Katari S, Gerson LF, et al. Inter- and intra-individual variation in allele-specific DNA methylation and gene expression in children conceived using assisted reproductive technology. PLoS Genet. 2010; 6, 1-14.

139. Gomes MV, Huber J, Ferriani RA, et al. Abnormal methylation at the KvDMR1 imprinting control region in clinically normal children conceived by assisted reproductive technologies. Mol Hum Reprod. 2009; 15, 471-477.

140. Turan N, Ghalwash MF, Katari S, et al. DNA methylation differences at growth related genes correlate with birth weight: a molecular signature linked to developmental origins of adult disease? BMC Med Genomics. 2012; 5, 10.

141. Chen S, Sun FZ, Huang X, et al. Assisted reproduction causes placental maldevelopment and dysfunction linked to reduced fetal weight in mice. Sci Rep. 2015; 5, 10596.

142. Li B, Chen S, Tang N, et al. Assisted reproduction causes reduced fetal growth associated with downregulation of paternally expressed imprinted genes that enhance fetal growth in mice. Biol Reprod. 2016; 94, 45.

143. Young LE, Fernandes K, McEvoy TG, et al. Epigenetic change in IGF2R is associated with fetal overgrowth after sheep embryo culture. Nat Genet. 2001; 27, 153-154.

144. Tan K, Zhang Z, Miao K, et al. Dynamic integrated analysis of DNA methylation and gene expression profiles in in vivo and in vitro fertilized mouse post-implantation extraembryonic and placental tissues. Mol Hum Reprod. 2016; 22, 485-498.

145. Farin PW, Piedrahita JA, Farin CE. Errors in development of fetuses and placentas from in vitro-produced bovine embryos. Theriogenology. 2006; 65, 178-191.

146. Wright K, Brown L, Brown G, et al. Microarray assessment of methylation in individual mouse blastocyst stage embryos shows that in vitro culture may have widespread genomic effects. Hum Reprod, 2011.

147. Le F, Wang LY, Wang N, et al. In vitro fertilization alters growth and expression of Igf2/H19 and their epigenetic mechanisms in the liver and skeletal muscle of newborn and elder mice. Biol Reprod, 2013.

148. Feuer SK, Liu X, Donjacour A, et al. Use of a mouse in vitro fertilization model to understand the developmental origins of health and disease hypothesis. Endocrinology. 2014; 155, 1956-1969.

149. Rexhaj E, Paoloni-Giacobino A, Rimoldi SF, et al. Mice generated by in vitro fertilization exhibit vascular dysfunction and shortened life span. J Clin Invest. 2013; 123, 5052-5060.

150. Rexhaj E, Pireva A, Paoloni-Giacobino A, et al. Prevention of vascular dysfunction and arterial hypertension in mice generated by assisted reproductive technologies by addition of melatonin to culture media. Am J Physiol Heart Circ Physiol. 2015; 309, H1151-H1156.
151. Burton GJ, Fowden AL, Thornburg KL. Placental origins of chronic disease. Physiol Rev. 2016; 96, 1509-1565.

152. Sferruzzi-Perri AN, Camm EJ. The programming power of the placenta. Front Physiol. 2016; 7, 33.

153. Barker DJ, Bull AR, Osmond C, et al. Fetal and placental size and risk of hypertension in adult life. BMJ. 1990; 301, 259-262.

154. Eriksson JG, Kajantie E, Thornburg KL, et al. Mother's body size and placental size predict coronary heart disease in men. Eur Heart J. 2011; 32, 2297-2303.

155. de Waal E, Vrooman LA, Fischer E, et al. The cumulative effect of assisted reproduction procedures on placental development and epigenetic perturbations in a mouse model. Hum Mol Genet. 2015; 24, 6975-6985.

156. Bloise E, Lin W, Liu X, et al. Impaired placental nutrient transport in mice generated by in vitro fertilization. Endocrinology. 2012; 153, 3457-3467.

157. Lalosevic D, Tabs D, Krnojelac D, et al. Histological characteristics of placentas from assisted reproduction programs. Med Pregl. 2003; 56, 521-527.

158. Joy J, Gannon C, McClure N, et al. Is assisted reproduction associated with abnormal placentation? Pediatr Dev Pathol. 2012; 15, 306-314.

159. Zhang Y, Zhao W, Jiang Y, et al. Ultrastructural study on human placentae from women subjected to assisted reproductive technology treatments. Biol Reprod. 2011; 85, 635-642.

160. Daniel Y, Schreiber L, Geva E, et al. Do placentae of term singleton pregnancies obtained by assisted reproductive technologies differ from those of spontaneously conceived pregnancies? Hum Reprod. 1999; 14, 1107-1110.

161. Haavaldsen C, Tanbo T, Eskild A. Placental weight in singleton pregnancies with and without assisted reproductive technology: a population study of 536,567 pregnancies. Hum Reprod. 2012; 27, 576-582.

162. Choux C, Carmignac V, Bruno C, et al. The placenta: phenotypic and epigenetic modifications induced by assisted reproductive technologies throughout pregnancy. Clin Epigenetics. 2015; 7, 87.

163. Henningsen AA, Gissler M, Skjaerven R, et al. Trends in perinatal health after assisted reproduction: a Nordic study from the CoNARTaS group. Hum Reprod. 2015; 30, 710-716.

164. Hansen M, Bower C. The impact of assisted reproductive technologies on intra-uterine growth and birth defects in singletons. Semin Fetal Neonatal Med. 2014; 19, 228-233.

165. Miller LM, Hodgson R, Wong TY, et al. Single embryo transfer for all? Aust NZJ Obstet Gynaecol, 2016.

166. Pandian Z, Marjoribanks J, Ozturk O, et al. Number of embryos for transfer following in vitro fertilisation or intracytoplasmic sperm injection. Cochrane Database Syst Rev. 2013; CD003416.

167. Evans J, Hannan NJ, Edgell TA, et al. Fresh versus frozen embryo transfer: backing clinical decisions with scientific and clinical evidence. Hum Reprod Update. 2014; 20, 808-821.

168. Sazonova A, Kallen K, Thurin-Kjellberg A, et al. Obstetric outcome after in vitro fertilization with single or double embryo transfer. Hum Reprod. 2011; 26, 442-450. 